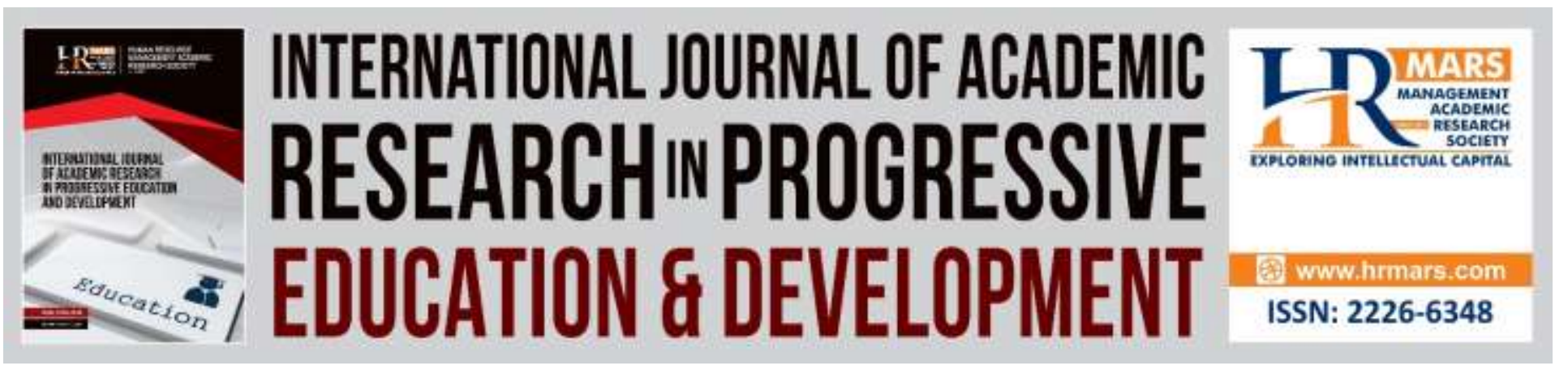

\title{
Self-Efficacy based on Teaching Experience Among Teachers Sekolah Menengah Kebangsaan Agama in Malaysia
}

\author{
Azlin Zainal Abidin, Azlin Norhaini Mansor \& Jamalullail Abdul Wahab
}

To Link this Article: http://dx.doi.org/10.6007/IJARPED/v8-i2/5693

DOI: $10.6007 /$ IJARPED/v8-i2/5693

Received: 18 Jan 2019, Revised: 23 Feb 2019, Accepted: 18 March 2019

Published Online: 25 March 2019

In-Text Citation: (Abidin, Mansor, \& Wahab, 2019)

To Cite this Article: Abidin, A. Z., Mansor, A. N., \& Wahab, J. A. (2019). Self-Efficacy based on Teaching Experience Among Teachers Sekolah Menengah Kebangsaan Agama in Malaysia. International Journal of Academic Research in Progressive Education and Development, 8(2), 176-186.

Copyright: (C) 2019 The Author(s)

Published by Human Resource Management Academic Research Society (www.hrmars.com)

This article is published under the Creative Commons Attribution (CC BY 4.0) license. Anyone may reproduce, distribute, translate and create derivative works of this article (for both commercial and non-commercial purposes), subject to full attribution to the original publication and authors. The full terms of this license may be seen

at: http://creativecommons.org/licences/by/4.0/legalcode

Vol. 8(2) 2019, Pg. 176 - 186

http://hrmars.com/index.php/pages/detail/IJARPED

JOURNAL HOMEPAGE

Full Terms \& Conditions of access and use can be found at http://hrmars.com/index.php/pages/detail/publication-ethics 


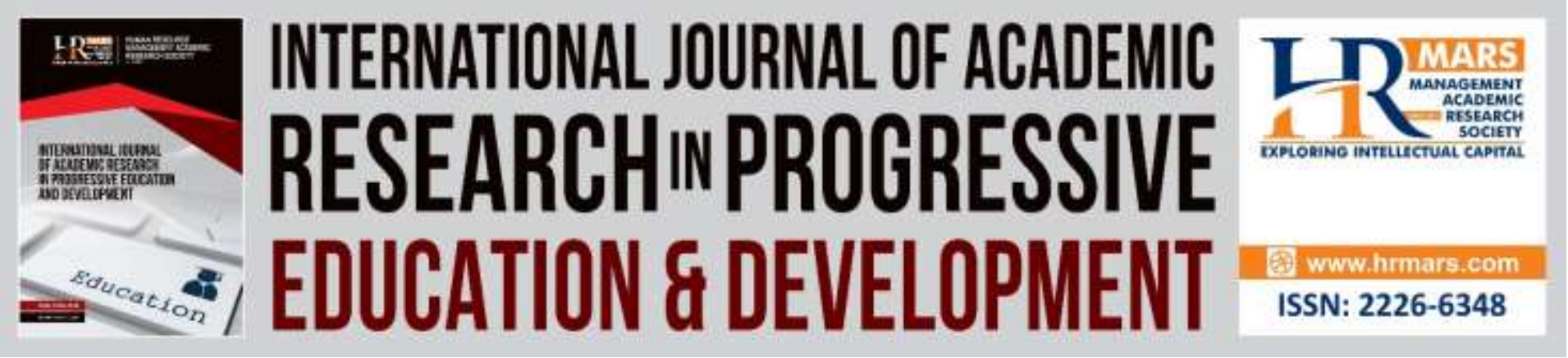

\title{
Self-Efficacy based on Teaching Experience Among Teachers Sekolah Menengah Kebangsaan Agama in Malaysia
}

\author{
Azlin Zainal Abidin \\ Institute Aminuddin Baki, Ministry of Education Malaysia \\ Azlin Norhaini Mansor \& Jamalullail Abdul Wahab \\ Faculty of Education, The National University of Malaysia
}

\begin{abstract}
Self-efficacy in this study refers to the three main aspects, namely, decision-making skills, determination and performance improvement among teachers. This study was conducted to identify the different levels of self-efficacy among teachers Sekolah Menengah Kebangsaan Agama in Malaysia based on their teaching experience. The survey study was conducted using questionnaires as the main instruments and only focus on 500 respondents consisting of several zones in Malaysia, namely the zone to the north, south, east and central zone. The data obtained in this study were analyzed by Statistical Package for Social Science (SPSS) software, using TwoWay MANOVA only. The findings showed that there was no significant difference between teaching experience among teachers Sekolah Menengah Kebangsaan Agama in Malaysia. Therefore, all parties including teachers themselves need to take action to improve and increase the level of selfefficacy among teachers Sekolah Menengah Kebangsaan Agama in Malaysia to the level of selfefficacy in the best conditions and satisfactory.
\end{abstract}

Keywords: Self-Efficacy, Decision-Making Skills, Determination, Performance Improvement

\section{Introduction}

Teachers are the main pulse in order to produce and strengthen the next generation to impart knowledge to them. In fact, the teacher is also a socialization agent that acts as an agent of change, particularly in the field of education through the establishment of an active mind and help build an honorable personality. In addition, to ensure that the next generation adheres to the religion, culture, society and the state, then the teacher must act as a booster of national education transformation (Jaafar \& Tamuri, 2012). 
In a world of increasingly advanced technology also affect the workload of a teacher. Therefore, teachers should have patience in carrying out their tasks, that is educating the younger generation (Din, 2011). The same situation was also felt by the teachers of Sekolah Menengah Kebangsaan Agama, where they are seen to have a greater responsibility in helping the current generation and the future through the implementation of values and the formation of a noble character (Tamuri, 2012).

Good teachers are teachers who can guide students toward a better, that has the characteristics of Muslim holistic and balanced in terms of spiritual, physical, intellectual and emotional as contained in the National Education Philosophy. A good teachers also should based on the Qur'an and Sunnah as has been taught in the religion of Islam itself. This situation is seen very compatible with the goal of becoming the root of the national secondary school construction religion in Malaysia, the dignity of the Qur'an and Sunnah which is fundamental to human life (Jasmi \& Tamuri, 2007).

\section{Self-Efficacy}

According to Bandura (1977), self-efficacy is the belief or the ability of an individual to ensure their goal successfully achieved through good planning and implementation. Hence, good planning and implementation so as to achieve the goal, actually helping a person to be more confident about the task that will be given to him later. Whereas, according to Schwätzer (1992) stated that selfefficacy is a form of belief in something new and difficult, need to be face of everyday life. Therefore, self-efficacy is a concept related to beliefs that involve the design through to implementation that can be achieved by a person includes in the face of everyday life.

Self-efficacy actually the basis of human motivation, well-being and personal achievement. This is because if an individual is given faith, then they will work harder to ensure that all objectives are achieved. Bandura is the pioneer of the concept of self-efficacy because he has brought a change of the concepts related to trust, and ultimately creating a theory related to socio-cognitive factors of self-regulation and achievement.

In this study, self-efficacy seen divided into three main aspects, namely, decision-making skills, determination and performance improvement and this aspect is only focused on teachers at Sekolah Menengah Kebangsaan Agama. Figure 1 shows the three main aspects of self-efficacy in this study; 


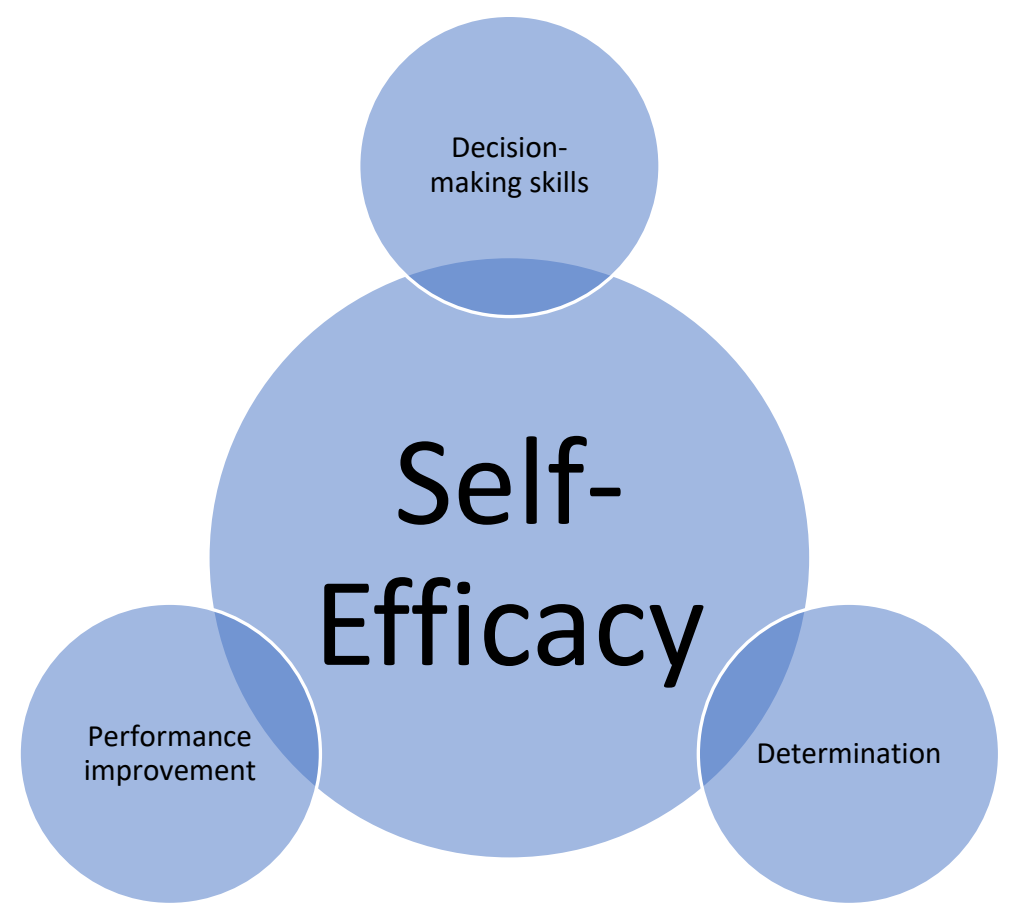

Figure 1: Self-Efficacy

\section{Problem Statement}

Provision of qualified teachers is the main problem faced by the education policy makers in each country, as supported by Corcoran (2007). Previously, the task of teaching and educating children is the responsibility of parents, but now the task is undertaken by the teacher. In addition, there is a theory which states that the parents were among the first and most important in moral development of children. However, teachers have more influence on the moral development of the children compared to parents. This can be seen through the study of Tamura (2011), where the teachers of Sekolah Menengah Kebangsaan Agama has a R-value that is higher than the parents.

In the face of challenges, responsibilities and scenarios students nowadays, the ability and capacity of the teachers affected by the teachers' beliefs (Coady et. Al., 2011) and according to Bandura (1994) states that teachers' beliefs can be classified as self-efficacy. Therefore, the level of self-efficacy among teachers of Sekolah Menengah Kebangsaan Agama Malaysia viewed directly affect the practice of learning and teaching as well as the personality of the teacher and in turn affects the academic achievement and personality of students (Donna, 2007).

In addition, previous studies also prove that self-efficacy is one of the main and most important elements in the learning process that can affect the quality of the teacher (Mason, 2010; Steele, 2010). In the context of education in Malaysia, a study on the efficacy study among teachers are still poorly implemented. There are very few studies using efficacy studies as one of the variables, such studies are Sin (2001); Kui (2006); Rorlinda (2009). 
INTERNATIONAL JOURNAL OF ACADEMIC RESEARCH IN PROGRESSIVE EDUCATION AND DEVELOPMENT

Vol. 8, No. 2, 2019, E-ISSN: 2226-6348 @ 2019 HRMARS

\section{Purpose of the Study}

This study aims to identify the different levels of self-efficacy, which consists of decision-making skills, determination and performance improvements based on teaching experience among teachers of Sekolah Menengah Kebangsaan Agama Malaysia.

\section{Research Methodology}

The study design is a process that involves the procedures related to data processing which includes a number of variables involved in a study. This study is a survey research using questionnaires as the main instrument, in which this questionnaire is to identify the level of selfefficacy of teachers of Sekolah Menengah Kebangsaan Agama Malaysia. The questionnaire covers aspects of decision-making skills, determination and performance improvements.

5 Likert scale questionnaire were chosen to represent the questionnaire in this study. 5 Likert scale selection purposes is to ensure that the respondents have a more appropriate to the circumstances of each (Weirsma, 1995). According to Cresswell (2005) states that the instrument is divided into several parts, the existing instrument, a modified instrument, and an instrument built himself. The study used an instrument that has been modified as supported by Shuhaida (2015). For the data analysis, this study uses statistical inference only because this study only focused on identifying the different levels of self-efficacy in terms of decision-making skills, determination and performance improvements based on experience. Inferential statistics used in this study is a one-way MANOVA analysis.

In addition, the sample is one part of the population, namely a large group. In this study, the population is a group of teachers at Sekolah Menengah Kebangsaan Agama Malaysia, while in this study only used a total of 500 teachers selected from Sekolah Menengah Kebangsaan Agama Malaysia. The sample in this study using purposive sampling, where selected individuals in the population is eligible respondents.

\section{Findings and Discussion}

500 teachers from Sekolah Menengah Kebangsaan Agama Malaysia was chosen as respondents for this study. A total of 106 teachers from Sekolah Menengah Kebangsaan Agama has taught from 05 years, while 116 people have been taught from 6-10 years old, the next is the 53 teachers who have been teaching for 11-15 years and a total of 225 teachers have been teaching for 6 years and up at Sekolah Menengah Kebangsaan Agama. Demographic profile of the study are shown in detail as follows; 
INTERNATIONAL JOURNAL OF ACADEMIC RESEARCH IN PROGRESSIVE EDUCATION AND DEVELOPMENT

Vol. 8, No. 2, 2019, E-ISSN: $2226-6348$ @ 2019 HRMARS

Table 1: Demographic Profile

\begin{tabular}{|c|c|c|c|}
\hline Profile & Demography & Frequency & Percentage \\
\hline $\begin{array}{c}\text { Teaching } \\
\text { Experience }\end{array}$ & $0-5$ Year & 106 & 21.2 \\
\cline { 2 - 4 } & $6-10$ Year & 116 & 23.2 \\
\cline { 2 - 4 } & $11-15$ Year & 53 & 10.6 \\
\cline { 2 - 4 } & 16 Year and above & 225 & 45.0 \\
\hline
\end{tabular}

\section{Self-Efficacy Difference by Teaching Experience}

Before MANOVA analysis conducted, researchers have tested first. The test is carried out to determine the homogeneity of variance-covariance matrix by using the tests Box's M. The importance of this test is to determine whether the variance-covariance among the dependent variables are the same or the opposite, across all the independent variables. This is an important prerequisite for MANOVA test. Table 2 shows the results of tests Box's M;

Table 2: Tests Box's M Self-Efficacy by Teaching Experience

\begin{tabular}{|c|c|c|c|c|}
\hline Box's M & F-value & df1 & df2 & Sig. \\
\hline 211.507 & 4.806 & 42 & 18051 & 0.000 \\
\hline
\end{tabular}

According to Table 2 shows that there is a difference between the variance-covariance significant among the dependent variable for all level of independent variables $(F=4.806, p=0.000)$. This means that the variance-covariance dependent variable is a homogenous across all independent variables. Table 3 shows the results of the analysis of Two-Way MANOVA mean differences based on experience teaching self-efficacy.

Table 3: Two-Way MANOVA analysis Self Efficacy Based Teaching Experience

\begin{tabular}{|c|c|c|c|c|c|}
\hline Effect & $\begin{array}{c}\text { Wilks' } \\
\text { Lambda } \\
\text { Value }\end{array}$ & F Value & $\begin{array}{c}\text { DK within } \\
\text { group }\end{array}$ & $\begin{array}{c}\text { DK between } \\
\text { group }\end{array}$ & Sig \\
\hline Teaching Experience & 0.980 & 1.083 & 9 & 1192 & 0.373 \\
\hline
\end{tabular}

Based on Table 3 shows that the comparison of the mean between self-efficacy with teaching experience, in which the value of Wilks' $\lambda=0.980, F(9,1192)=1.083$ and $p=0.373(p>0.05)$. This finding is consistent with studies Maulod Shafinaz A. (2017) stated that there was no significant difference between self-efficacy based on teaching experience among teachers. This situation 
INTERNATIONAL JOURNAL OF ACADEMIC RESEARCH IN PROGRESSIVE EDUCATION AND DEVELOPMENT

Vol. 8, No. 2, 2019, E-ISSN: 2226-6348@ 2019 HRMARS

exists because the teachers seen to be doing the same workload almost every day and it is also supported by Munaim (2013).

There are multiple ANOVA analysis was performed to see the difference in mean score for each dependent variable in self-efficacy based on teaching experience. Table 4 shows the comparison of the mean and standard deviation for each aspect of self-efficacy based on teaching experience.

Table 4: Comparison of the Mean and Standard Deviation for Each Aspect of Self-Efficacy based on Teaching Experience

\begin{tabular}{|c|c|c|c|c|}
\hline Self-Efficacy & Teaching Experience & $\mathrm{N}$ & Mean & $\begin{array}{l}\text { Standard } \\
\text { Deviation }\end{array}$ \\
\hline \multirow{6}{*}{$\begin{array}{l}\text { Decision-Making } \\
\text { Skills }\end{array}$} & $<5$ Years & 106 & 3.71 & 0.49 \\
\hline & $6-10$ Years & 116 & 3.46 & 0.85 \\
\hline & & & & \\
\hline & $11-14$ Years & 53 & 3.63 & 0.50 \\
\hline & $>15$ Years & 225 & 3.71 & 0.60 \\
\hline & Total & 500 & 3.64 & 0.65 \\
\hline \multirow{5}{*}{ Determination } & $<5$ Years & 106 & 4.18 & 0.39 \\
\hline & $6-10$ Years & 116 & 4.19 & 0.37 \\
\hline & $11-14$ Years & 53 & 4.23 & 0.53 \\
\hline & $>15$ Years & 225 & 4.33 & 0.44 \\
\hline & Total & 500 & 4.26 & 0.43 \\
\hline \multirow{5}{*}{$\begin{array}{l}\text { Performance } \\
\text { Improvement }\end{array}$} & $<5$ Years & 106 & 4.11 & 0.43 \\
\hline & $6-10$ Years & 116 & 4.17 & 0.43 \\
\hline & $11-14$ Years & 53 & 4.19 & 0.49 \\
\hline & $>15$ Years & 225 & 4.24 & 0.39 \\
\hline & Total & 500 & 4.19 & 0.42 \\
\hline
\end{tabular}

Self-efficacy for aspects of decision-making skills, determination and performance improvements based on teaching experience showed that teachers who had been teaching for more than 15 years had a higher mean compared to the other teachers. Even new teachers may have seen a high level of self-efficacy compared to a teacher who has been caused by several factors such as environmental factors that can influence it (Aziah et. Al., 2015). Thus, teaching experience among teachers viewed also can affect the level of self-efficacy of teachers. 
INTERNATIONAL JOURNAL OF ACADEMIC RESEARCH IN PROGRESSIVE EDUCATION AND DEVELOPMENT

Vol. 8, No. 2, 2019, E-ISSN: 2226-6348 @ 2019 HRMARS

Table 5: One-way ANOVA analysis aspects in the Self-Efficacy of Teaching Experience

\begin{tabular}{|c|c|c|c|c|c|c|}
\hline Demography & Self-Efficacy & $\begin{array}{c}\text { Type III Total } \\
\text { Square }\end{array}$ & Df & $\begin{array}{c}\text { Total } \\
\text { Square }\end{array}$ & $\mathrm{F}$ & Sig. \\
\hline Teaching & Decision-making skills & 0.741 & 3 & 0.247 & 0.614 & 0.606 \\
\hline \multirow[t]{2}{*}{ Experience } & Determination & 1.178 & 3 & 0.393 & 2.090 & 0.101 \\
\hline & $\begin{array}{l}\text { Performance } \\
\text { Improvement }\end{array}$ & 0.700 & 3 & 0.233 & 1.296 & 0.275 \\
\hline
\end{tabular}

Based on Table 5, comparative aspects of self-efficacy based on teaching experience, it is found that there was no significant difference in terms of decision-making skills ( $F=0.614$ and sig $=0606)$, the determination $(F=2.090$ and sig $=0.101)$ and the performance improvement $(F=\operatorname{sig}=1.296$ and 0.275).

\section{Conclusion}

This study was conducted to identify the differences in self-efficacy for aspects of decision-making skills, determination and performance improvements based on experience. In conclusion, the results showed that there was no significant difference between self-efficacy of teachers for aspects of decision-making, persistence and performance improvements based on the experience of teaching at Sekolah Menengah Kebangsaan Agama in Malaysia. The information obtained through this study can be used by the Ministry of Education in order to improve and enhance the level of self-efficacy of teachers, especially teachers of Sekolah Menengah Kebangsaan Agama.

\section{Corresponding Author}

Azlin Zainal Abidin, Faculty of Education, The National University of Malaysia, Malaysia Email: azlin912@yahoo.com

\section{References}

Abu-Tineh M. A., Khasawneh, S. A. \& Khalaileh, H. A. 2011. Teacher Self Efficacy and Classroom Management Styles in Jordanian Schools. Management in Education 25(4) : 175-181.

Adam, K. \& Tan, S. (2004). Master Your Mind Design Your Destiny. Singapore : Adam Khoo Learning Publisher.

Bandura, A. 1993. Perceived Self-Efficacy in Cognitive Development and Functioning. Educational Psychologist 28(2) : 117-148.

Bandura, A. 1994. Self-Efficacy. Dlm. Ramachaudran, V. R. (pnyt). Encylopedi of Human Behavior, hlm. 71-81. New York : Academic Press.

Bandura, A. 1997. Self-Efficacy in Changing Society. New York : Cambridge University Press. Casey, M. 2011. Perceived Efficacy and Preparedness of Beginning Teachers to Differentiate Instruction, Tesis PhD, Faculty of Leadership, Johnson \& Wales University. 
INTERNATIONAL JOURNAL OF ACADEMIC RESEARCH IN PROGRESSIVE EDUCATION AND

DEVELOPMENT

Vol. 8, No. 2, 2019, E-ISSN: 2226-6348 @ 2019 HRMARS

Coady, M., Harper, C. \& De Jong, E. 2011. From Preservice to Practice : Mainstream Elementary Teacher Beliefs of Preparation and Efficacy With English Language Learners in the State of Florida. Bilingual Research Journal 34(2) : 223-239.

Corcoran, T. B. (2007). Teaching Matters : How State and Local Policymakers Can Improve the Quality of Teachers and Teaching. Philadelphia, PA : Consortium for Policy Research in Education, University of Pennsylvania.

Darling-Hammond, L., Wei, R. C., Andree, A., Richardson, N. \& Orphanos, S. (2009). Professional Learning in the Learning Profession : A Status Report on Teacher Development in the United States and Abroad. Washington, DC : National Staff Development Council.

Din, A., Md. 2011. Pendidikan Islam Malaysia : Isu dan Cabaran. Kertas kerja Kongres Pendidikan Islam Kebangsaan 2011. Anjuran Kementerian Pelajaran Malaysia. Dinasty Hotel Kuala Lumpur, 4-7 Disember.

Don, Y., Ismail, A. \& Daud, Y. (2006). Pembangunan dan Kepimpinan Pelajar Sekolah di Malaysia. Kuala Lumpur : PTS Professional Publishing Sdn. Bhd.

Gazali, K. 2005. Pengaruh Efikasi Kendiri dan Lokus Kawalan Terhadap Komitmen Mengajar di Kalangan Guru-Guru Kanan Teknikal dan Vokasional. Tesis. Dr. Fal, Pusat Pengajian IImu Pendidikan Universiti Sains Malaysia.

Hassan, M., K. 2011. Pendidikan Yang Membentuk Syakhsiah Bangsa dan Proses Islamisasi. Kertas kerja Kongres Pendidikan Islam Kebangsaan 2011. Anjuran Kementerian Pelajaran Malaysia, Dynasty Hotel Kuala Lumpur, 4-7 Disember.

Henson, R. K., Bennett, D. T., Sienty, S. F. \& Chambers, S. M. 2000. The Relationship between Means-End Task Analysis and Context Specific and Global Efficacy in Emergency Certification Teachers; Exploring a New Model of Efficacy. Kertas kerja Annual Meeting of the American Educational Research Association. Anjuran American Educational Research Association. New Orleans, LA, 24-28 April.

Henson, R. K., Kogan, L. R. \& Vacha-Haase, T. 2001. A Reliability Generalization Study of the Teacher Efficacy Scale and Related Instruments. Educational and Psychlogical Measurement 61(3) : 404-420.

Jaafar, N. \& Tamuri, A., H. 2012b. Guru Pendidian Islam Sebagai Murabbi : Satu Keperluan Dalam Mendepani Remaja Islam Abad 21. Prosiding Seminar Antarabangsa Perguruan dan Pendidikan Islam 2012, hlm. 239-248.

Jasmi, K., A. 2010. Guru Cemerlang Pendidikan Islam Sekolah Menengah di Malaysia : Satu Kajian Kes. Tesis Dr. Fal. Fakulti Pendidikan, Universiti Kebangsaan Malaysia.

Johari, K., Ismail, Z., Osman, S., \& Othman, A., T. 2009. Pengaruh Jenis Latihan Guru dan Pengalaman Mengajar Terhadap Efikasi Guru Sekolah Menengah. Jurnal Pendidikan Malaysia 34(3-14).

Kui L, K,. 2006. Pengaruh Faktor Terpilih Terhadap Efikasi Kendiri Guru Di Sekolah Menengah di Negeri Sarawak. Tesis Dr. Fal., Universiti Putra Malaysia.

Mason, J. H. 2010. Exploring the Influence of High-Stakes Testing and Accountability on Teachers' Professional Identities through the Factors of Instructional Practice, Work Environment and Teacher Efficacy. Tesis Ph.D, Western Carolina University.

Milson, A.J. 2001. Teacher efficacy \& character education. Paper presented at the Annual Meeting of the American Educational Research Association. Seattle, W.A., April 10-14. ED4542122 
INTERNATIONAL JOURNAL OF ACADEMIC RESEARCH IN PROGRESSIVE EDUCATION AND

DEVELOPMENT

Vol. 8, No. 2, 2019, E-ISSN: 2226-6348 @ 2019 HRMARS

Mohamed, A., K. (2005). Pengurusan Pendidikan Di Sekolah Dari Perspektif Islam. Johor : Universiti Teknologi Malaysia.

Murshidi, R. 2005. Factors Associated with Sense of Efficacy among First Year Teachers in Sarawak. Tesis Dr. Falsafah, Universiti Putra Malaysia.

Osman, R. 2009. Hubungan Kualiti Penyelidaan Pengajaran dan Pembelajaran Dengan Komitmen dan Efikasi Guru. Tesis Dr. Fal, Fakulti Pendidikan, Universiti Utara Malaysia.

Pajares, F. (1996). Self-efficacy beliefs in academic setting. Review in Educational Research, 66(44). $543-578$.

Pas, E. T., Bradshaw, C. P. \& Hershfeldt, P. A. 2011. Teacher-and School-Level Predictors of Teacher Efficacy and Burnout : Identifying Potential Areas for Support. Journal of School Psychology

Rahman, S, A. 2005. Pengaruh Iklim Sosial dan Iklim Tugasan Terhadap Sikap Kerja Guru-Guru, Pencapaian Pelajar dan Keberkesanan Sekolah, Tesis Dr. Fal. Fakulti Pendidikan, Universiti Kebangsaan Malaysia.

Rimm-Kaufman, S. E. \& Sawyer, B. E. 2004. Primary-Grade Teachers' Self-Efficacy Beliefs, Attitudes toward Teaching and Disciplin and Teaching Practice Priorities in Relation to the "Responsive Classroom" Approach. The Elementary School Journal 321-341.

Settlage, J., Southerland, S. A., Smith, L. K. \& Ceglie, R. 2009. Constructing a Doubt-Free Teaching Self : Self-Efficacy, Teacher Identity and Science Instruction within Diverse Settings. Journal of Research in Science Teaching 46(1) : 102-125.

Sin, I. 2001. Pengaruh Kepimpinan Pengajaran, Kepimpinan Transformasi dan Gantian Kepada Kepimpinan Ke Atas Komitmen Terhadap Organisasi, Efikasi dan Kepuasan Kerja Guru. Tesis Dr. Fal. Fakulti Pendidikan, Universiti Kebangsaan Malaysia.

Steele, N. A. 2010. Three Characteristics of Effective Teachers. Update : Applications of Research in Music Education 28 (2) : 71-78.

Suhid, A. 2005. Pemantapan Komponen Akhlak Dalam Pendidikan Islam Bagi Menangani Era Globalisasi. Jurnal Kemanusiaan 6 : 95-104.

Tamuri, Ab. H. 2012. The Role of Mosque : The Integration Approach of Teaching and Learning Process. Anjuran PIMM \& The Islamic Academy Cambridge, United Kingdom, International Conference on Research in Islamic and Arabic Language Education 2012. Elaf

Tamuri, Ab., H. 2011. Penghayatan Islam Melalui Pengajaran dan Pembelajaran. Kertas kerja Kongres Pendidikan Islam Kebangsaan. Anjuran Kementerian Pelajaran Malaysia. Dinasty Hotel Kuala Lumpur, 4-7 Disember.

Weisel, A. \& Dror, O. 2006. School Climate, Sense of Efficacy and Israeli Teachers' Attitudes toward Inclusion of Students with Special Needs. Education, Citizenship and Social Justice 1(2) : 157174.

YImaz, H. \& Lava, P. 2008. The Effect of the Teaching Practice on Pre-Service Elementary Teachers' Science Teaching Efficacy and Classroom Management Beliefs. Eurasia Journal of Matematics, Science \& Technology Education 4(1) : 45-54.

Yoon, S. J. 2002. Teacher Characteristics as Predictors of Teacher-Student Relationships : Stress, Negative Affect and Self-Efficacy. Social Behavior and Personality : an International Journal 30(5) : 485-493. 
INTERNATIONAL JOURNAL OF ACADEMIC RESEARCH IN PROGRESSIVE EDUCATION AND DEVELOPMENT

Vol. 8, No. 2, 2019, E-ISSN: 2226-6348 @ 2019 HRMARS

Yusof, R. 2009. Kecerdasan Emosi, Efikasi Kendiri dan Sumbangan Terhadap Komitmen Guru Kaunseling Sekolah Menengah. Tesis Dr. Fal, Fakulti Pendidikan, Universiti Kebangsaan Malaysia.

Yusoff, S. 2004. Pengaruh Efikasi-Kendiri dan Kecerdasan Emosi Guru Besar Terhadap Efikasi Kolektif Guru dan Iklim Organisasi Sekolah Tesis Dr. Fal, Pusat Pengajian Pendidikan Jarak Jauh, Universiti Sains Malaysia. 